\title{
A General Study on the Evaluation of Physico-Chemical Factors of Ramgarh Lake
}

\author{
Farindra Tiwari \\ P. G. Department of Zoology, M. G. P. G. College, Gorakhpur, 273 001, UP, India.
}

\author{
How to cite this paper: Farindra Tiwari. \\ (2021) A General Study on the Evaluation \\ of Physico-Chemical Factors of Ramgarh \\ Lake. International Journal of Food \\ Science and Agriculture, 5(2), 322-325. \\ DOI: 10.26855/ijfsa.2021.06.017 \\ Received: April 16, 2021 \\ Accepted: May 20, 2021 \\ Published: June 9, 2021 \\ *Corresponding author: Farindra \\ Tiwari, P. G. Department of Zoology, \\ M. G. P. G. College, Gorakhpur, 273 \\ 001, UP, India. \\ Email: drfarindra_mgpg@rediffmail.com
}

\begin{abstract}
Water is the essential part of life and it is assumed that next world war will be based on the scarcity of it. When water is polluted by various ways that means it affects flora and fauna of that area. The people living near the water bodies depend on it for irrigation and pisciculture activities. Water sample collected from Ramgarh Lake located in eastern part of Gorakhpur City of Eastern Uttar Pradesh state. Water is most precious natural resource expected to before from pollution. The physiochemical parameters are atmospheric temperature (AT), water temperature (WT), $\mathrm{pH}$, electrical conductivity (EC), total dissolve solid (TDS), acidity (acid), alkalinity (alk), carbon dioxide $\left(\mathrm{CO}_{2}\right)$, dissolve oxygen (DO), were mentioned on monthly basis for period of one time annual cycle that is January 2018 to December 2019. The result revealed that the reservoir water is useful for human use.
\end{abstract}

\section{Keywords}

Irrigation, Ramgarh Lake, Parameters

\section{Introduction}

In the last two decades, there has been a growing necessity for conservation of our resources, especially water. At the same time, growing populations, progressive industrialization and intensification of agriculture have led to increased pollution of surface waters. This induces ecological imbalances, deleterious for sustained development of fisheries resources, which has necessitated the suspension of the beneficial uses of these water bodies in some places [1]. Nevertheless, an increasing number of specially created environmental agencies are being assigned the task of conserving water quality for all uses within one river or lake basin. In conserving water quality for multipurpose use, a holistic approach was recommended [2-5] in which all-immediate and potential interests in the water basin are considered simultaneously. Experience has shown that only an ecologically healthy fresh water ecosystem fulfils this goal and the ecology of the flora and fauna of the ecosystem best measure this [6]. Water quality monitoring is of immense importance in the conservation of water resources for fisheries, water supply and other activities; it involves the assessment of physico-chemical parameters of water bodies. Impacted changes in the quality of water are reflected in the biotic community structure, with the vulnerable dying, while the most sensitive species act as indicators of water quality [3]. The present study was conducted for one year that is Jan 2018 to Dec 2019 through the monthly sampling of Ramgarh Lake. The density of diversity of zooplanktons is depending on water quality of reservoir. The zooplankton is microscopic free living floating organism, which occupy a central position between the autotrophy and other heterotrophs and from an important link in aquatic food web. Human life is living pattern without the presence of aquatic animals. All over the world, all fresh water habitats, lakes, ponds, reservoir, dams etc. The present paper deals with the result of water analysis of Ramgarh Lake.

\section{Materials and Methods}

\subsection{Area for the Study}

District Gorakhpur is situated in the north-east "Tarai" region of U.P. (India) and lies between $26.5^{\circ}-27.9^{\circ} \mathrm{N}$ and 
$83.4^{\circ}-84.26^{\circ} \mathrm{E}$ at an altitude of 95 metre above sea level. There are many temporary and residential water bodies of varying size in this region. The Ramgarh Lake is a shallow, perennial eutrophic lake situated at $26^{\circ} 44^{\prime} 9^{\prime \prime} \mathrm{N}$, and $83^{\circ} 24^{\prime}$ 16" E eastern side of the Gorakhpur town. It covers an area of about $15 \mathrm{~km}^{2}$ during summer and $22 \mathrm{~km}^{2}$ in the monsoon period. For the determination of heavy metal content in the lake water, five sampling sites (Site-1 Champa Devi, Site-2 Boat Club, Site-3 Sahara Estate, Site-4 RKBK Maruti Showroom Mohaddipur, Site-5 Singhadia Canal Pump) were selected (Figure 1). The water samples were collected monthly. The physiochemical parameters are atmospheric temperature (AT), water temperature (WT), electrical conductivity (EC), total dissolve solid (TDS), acidity (acid), alkalinity (alk), carbon dioxide $\left(\mathrm{CO}_{2}\right)$, dissolve oxygen (DO), were carried out on field. Physical chemical characteristics of water were estimated following standard method.

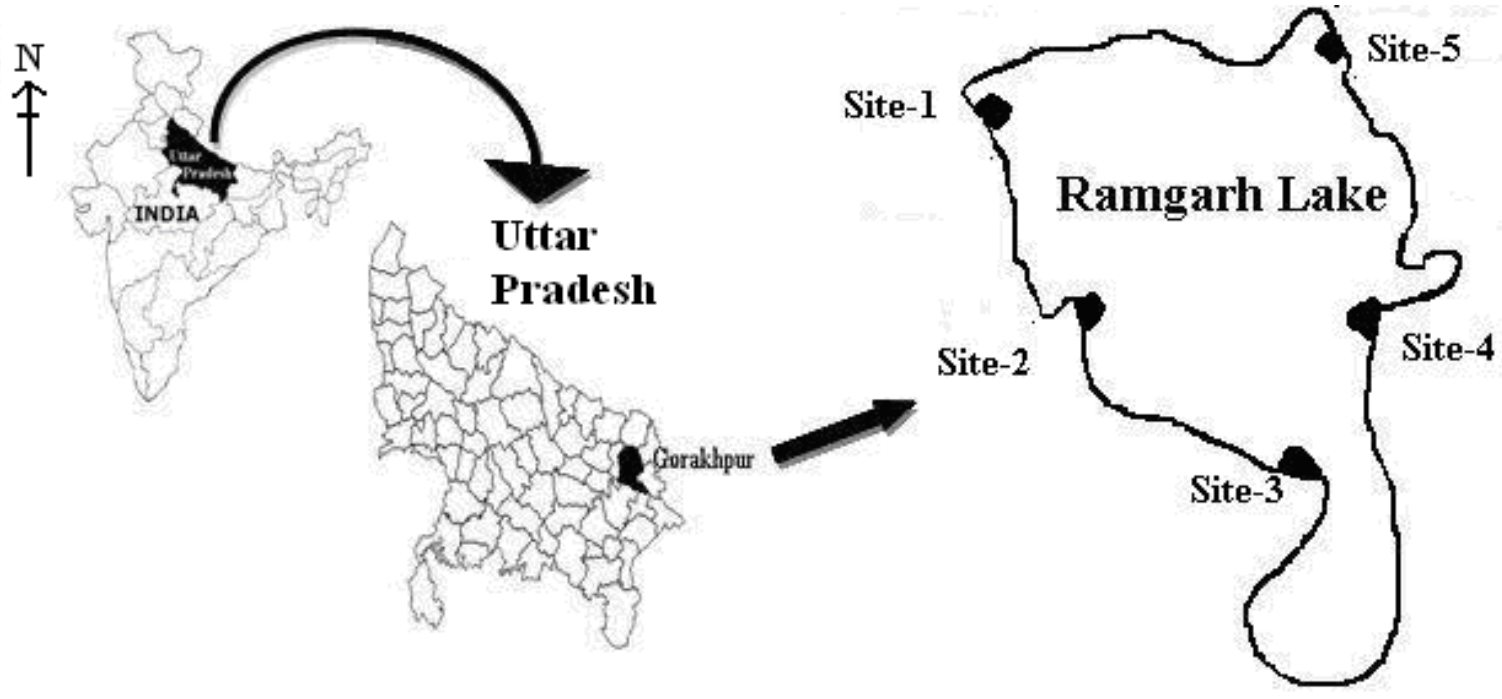

Figure 1. Sampling sites for the collection of water samples of Ramgarh Lake, Gorakhpur.

\section{Results and Discussion}

The present investigatory study of Ramgarh Lake reveals all parameters are in favorable range for aquatic life, irrigation and domestic use. Present studies showed $\mathrm{pH}$ range favorable for aquatic life, irrigation and domestic use. The investigated results are as follows.

Atmospheric temperature of surface water ranges from $24.6^{\circ} \mathrm{C}$ to $43.5^{\circ} \mathrm{C}$ during the study period. Minimum $\left(24.6^{0} \mathrm{C}\right)$ and maximum $\left(43.5^{\circ} \mathrm{C}\right)$ atmospheric temperature (AT) were recorded during winter and summer season respectively. The water temperature was maximum during summer $\left(43.5^{\circ} \mathrm{C}\right)$ and minimum during winter $\left(24.6^{\circ} \mathrm{C}\right)$ (see Table 1 and Table 2). The results show that water temperature varies with the atmospheric temperature. During the summer season, solar radiations are and clear sky condition enhanced the atmospheric temperature. Where the during monsoon season, rainfall and cloudy-skies brought down the atmospheric temperature and subsequently the water temperature to minimum.

Table 1. Monthly reading in four sites of Ramgarh Lake (Jan 2018 to Dec. 2018)

\begin{tabular}{ccccccccccc}
\hline Month & $\mathrm{AT}^{0} \mathrm{C}$ & $\mathrm{WT}^{0} \mathrm{C}$ & $\mathrm{pH}$ & $\mathrm{Ec} \mu \mathrm{s} / \mathrm{cm}$ & $\mathrm{TDS} \mathrm{mg} / \mathrm{l}$ & $\mathrm{ACID} \mathrm{mg} / \mathrm{l}$ & $\mathrm{Alk} \mathrm{mg/l}$ & $\mathrm{CO} \mathrm{m}_{2} / \mathrm{l}$ & $\mathrm{DO} \mathrm{mg} / \mathrm{l}$ \\
\hline Jan & 24.6 & 23.5 & 7.8 & 181 & 113 & 11.1 & 237 & 1.8 & 4.1 \\
Feb & 26.9 & 25.9 & 8.2 & 190 & 125 & 9.8 & 261 & 1.97 & 4.26 \\
Mar & 31.5 & 28.9 & 8.6 & 199 & 133 & 8.9 & 274 & 1.83 & 4.37 \\
Apr & 38.5 & 37.6 & 8.5 & 205 & 156 & 8.6 & 284 & 2.15 & 4.61 \\
May & 40.9 & 40.1 & 8.1 & 254 & 145 & 9.6 & 276 & 2.27 & 3.56 \\
Jun & 42.2 & 41.2 & 8.2 & 265 & 169 & 6.5 & 240 & 2.3 & 3.47 \\
Jul & 42.1 & 40.6 & 8.3 & 294 & 140 & 18.2 & 243 & 3.1 & 3.4 \\
Aug & 31.5 & 29.7 & 7.6 & 250 & 133 & 19.5 & 231 & 3.22 & 3.95 \\
Sep & 30.1 & 28.4 & 7.5 & 236 & 110 & 18.9 & 218 & 2.11 & 4.01 \\
Oct & 27.6 & 25.4 & 7.2 & 221 & 112 & 17.1 & 215 & 1.92 & 4.03 \\
Nov & 25.6 & 23.6 & 7.6 & 192 & 110 & 18.2 & 223 & 1.9 & 4 \\
Dec & 26.9 & 24.5 & 7.8 & 189 & 105 & 15.1 & 234 & 182 & 4.05 \\
\hline
\end{tabular}


Table 2. Monthly reading in four sites of Ramgarh lake (Jan 2019 to Dec. 2019)

\begin{tabular}{ccccccccccc}
\hline Month & $\mathrm{AT}^{0} \mathrm{C}$ & $\mathrm{WT}^{0} \mathrm{C}$ & $\mathrm{pH}$ & $\mathrm{Ec} \mu \mathrm{s} / \mathrm{cm}$ & $\mathrm{TDS} \mathrm{mg} / \mathrm{l}$ & ACID mg/l & Alk mg/l & $\mathrm{CO} 2 \mathrm{mg} / \mathrm{l}$ & $\mathrm{DO} \mathrm{mg} / \mathrm{l}$ \\
\hline Jan & 23.4 & 22.4 & 7.6 & 180 & 116 & 10.9 & 234 & 1.6 & 4.35 \\
Feb & 25.5 & 24.6 & 8.4 & 191 & 121 & 9.4 & 265 & 1.92 & 4.01 \\
Mar & 29.9 & 28.9 & 8.7 & 192 & 137 & 8.2 & 278 & 1.85 & 4.40 \\
Apr & 39.1 & 38.4 & 8.5 & 201 & 151 & 8.7 & 281 & 2.20 & 4.58 \\
May & 41.8 & 39.6 & 8.3 & 251 & 141 & 9.3 & 272 & 2.24 & 3.59 \\
Jun & 42.7 & 41.2 & 8.4 & 262 & 162 & 6.1 & 246 & 2.33 & 3.49 \\
Jul & 41.4 & 40.6 & 8.1 & 293 & 146 & 18.5 & 241 & 3.16 & 3.44 \\
Aug & 32.7 & 29.9 & 7.7 & 255 & 131 & 19.1 & 237 & 3.32 & 3.98 \\
Sep & 30.6 & 29.4 & 7.6 & 231 & 120 & 18.2 & 219 & 2.16 & 4.06 \\
Oct & 27.5 & 25.4 & 7.4 & 228 & 119 & 17.5 & 216 & 1.89 & 4.01 \\
Nov & 25.3 & 23.2 & 7.8 & 197 & 121 & 18.6 & 225 & 1.94 & 4.01 \\
Dec & 26.7 & 24.8 & 7.6 & 182 & 114 & 15.4 & 238 & 1.79 & 4.07 \\
\hline
\end{tabular}

$\mathrm{pH}$ value of all sample lies in the range of 7.2 to 8.6 are slightly alkaline and suitable to irrigation purpose that is there is no alkalinity hazard (7.2-8.1) during winter and higher value (8.1 to 8.6) during summer (see Table 1 and Table 2). Higher $\mathrm{pH}$ is normally associated with a high photosynthetic activity in water [7-9]. The $\mathrm{pH}$ of the water appears to be dependent upon the relative's quantities of calcium carbonate and bicarbonates, being alkaline when disposal of wastes also bring about changes in the $\mathrm{pH}[10,11]$ (See Table 1 and Table 2).

Electrical conductivity (EC) is a measure of the salt content of water in the form of ion. EC value ranges from 189 $\mu \mathrm{S} / \mathrm{cm}$ to $294 \mu \mathrm{S} / \mathrm{cm}$ with an average of $235 \mu \mathrm{S} / \mathrm{cm}$ (see Table 1 and Table 2). The month wise value shows the minimum during December. The concentration of EC increases during summer and reaches maximum in July. The increase in EC during pre monsoon period may be due to evaporation. This is in agreement with result obtained by Shankar et al. [12-15].

Total Dissolve Solid (TDS) are various kinds of minerals substances present in water. Some dissolve organic matter may also contribute to total dissolve solid. TDSA value ranges from $105 \mathrm{mg} / \mathrm{l}$ to $169 \mathrm{mg} / \mathrm{l}$ (see Table 1 and Table 2). The season wise value shows the minimum during winter. The concentration of TDS in water gives an idea about suitability of this water for various uses including potable water. All the values of TDS were within the (500 mg/l) highest desirable limit $[16,17]$.

Acidity is found maximum during winter and minimum during summer. Acidity values of all sample lies in the ranges of $17.1 \mathrm{mg} / \mathrm{l}$ to $34.2 \mathrm{mg} / \mathrm{l}$ (see Table 1 and Table 2). Acidity of water is its quantitative capacity to react with a strong base to designated $\mathrm{pH}$. Value of the acidity is about $200 \mathrm{mg} / \mathrm{l} \mathrm{[16]} \mathrm{and} \mathrm{observed} \mathrm{values} \mathrm{are} \mathrm{far} \mathrm{less} \mathrm{than} \mathrm{this,} \mathrm{in-}$ dicating that acidity of sample water is a safe range.

Total Alkalinity shows seasonal variation in the study. Alkalinity value ranges from $215 \mathrm{mg} / \mathrm{l}$ to $284 \mathrm{mg} / \mathrm{l}$. The values were high during the summer and low during winter. The fall in values during monsoon may be due to dilution of water. The high value of alkalinity indicates the presence of weak and strong base such as carbonate and hydroxide in the water body [18-20].

The carbon dioxide level fluctuated between $1.8 / \mathrm{l}$ to $2.5 \mathrm{mg} / \mathrm{l}$. The seasonal value was $3.82 \mathrm{mg} / \mathrm{l}$ in winter, $2.27 \mathrm{mg} / \mathrm{l}$ in summer and $3.22 \mathrm{mg} / \mathrm{l}$ in rainy season (see Table 1 and Table 2). Low value of free $\mathrm{CO}_{2}$ as observed during summer are mainly because of $\mathrm{CO}_{2}$ is utilized in the polysynthetic activities [20].

The dissolve oxygen is most important factor in fresh water life. In present study DO is ranged between $3.4 \mathrm{mg} / \mathrm{l}$ to $4.3 \mathrm{mg} / \mathrm{l}$. The average DO value were $3.56 \mathrm{mg} / \mathrm{l}$ in summer, $4.05 \mathrm{mg} / \mathrm{l}$ in winter and $3.95 \mathrm{mg} / \mathrm{l}$ during rainy season The value of DO was obtained as following order, winter $>$ rainy $>$ summer season in present study. The phenomenon of re-oxygenation of water during monsoon may be due to the circulation and mixing by in flow water monsoon rains [21-25]. It further progressed in winter may be due to the circulation by cooling and draw down the DO in water [26-27].

\section{Conclusion}

The present study concluded that the higher values of some parameters of the samples of Ramgarh Lake clearly indicate that it directly affects the floral and faunal population. They minimize the suitability of these samples for drinking purposes without treatment. But, after the filtration and disinfection, naturally present impurities can be removed in water, which provide its suitability for drinking and domestic purposes. People depend on this water are often prone to health hazards due to polluted drinking water. Therefore, some effective measures are urgently required to enhance the drinking water quality by delineating an effective water quality management plan for the region. 


\section{Acknowledgement}

The authors are thankful to the authorities of Mahatma Gandhi P. G. College, Gorakhpur for providing lab facilities.

\section{References}

[1] Barbour, M. T., J. Gerristen, B. D. Synder, and J. B. Stribbling. (1999). Rapid Bioassessment protocols for use in streams and wadeable rivers. Periphyton, Benthic Macroinvertebrates and Fish, Second edition EPA 842-B-99-002 USEPA, office of water, Washington D.C.

[2] Ogbogu, S. S. and A. T. Hassan. (1996). Effects of sewage on physico-chemical variables and Ephemeroptera (Mayfly) larvae of a stream reservoir. Journal of Aquatic Sciences, 11: 43-55.

[3] Ogbogu, S. S. (2001). Fundamentals of Ecology, W.B. Saunders Ltd. Philadelphia, USA 610.

[4] APHA. (1998). Standard methods for examination of waters and wastewaters, 20th ed. American public health authority, Washington D.C. USA 2112.

[5] Wetzel, R. G. and Likens, G. E. (1979). Limnological Analysis, W.B. Saunders Philadelphia USA 357.

[6] Boyd, C. E. (1981). Water quality in warm water fish ponds agricultural experimental station. Gaftmaster pub. Co. Alabama USA 359.

[7] Trivedy, R. K., Goel, P. K., and Trisal, C. L. (1987). Practical methods in ecology and environmental science Enviro media publication, Karad (India).

[8] Singhai, S., Ramani, G. M., and Gupta, U. S. (1990). Seasonal variation and relationship of different physiochemical characteristics in newly made Tawa Reservoir, Limnio logical (Berlin), Poll Res J., 21(1), 293-301.

[9] Govindaswamy, C. and Kannanm, K. (1991). Rotifer of the pichavarammangoves (Southeast coast of India) Hydrobiological approach, Mahasagar, Bull. Natl. Inst.Ocenogr., 24, 39-45.

[10] King, D. L. (1970). The role of carbon in eutrophication. Ecology. Res J., 42, 2035-2081.

[11] Olsen, R. D. and Sommerfeld, M. R. (1977). The physiochemical limnology of desert reservoir. Hydrobiologia, 3J(2), 117-129.

[12] Goel, P. K., Trivedi, R. K., and Bhave, S. V. (1985). Studies on the Limnology of few fresh water bodies in southwestern Maharastra, India. Res J. Environ, Pract, 5(1), 19-25

[13] Pearsall, W. H. (1930). Phytoplanktons in the English lake1, The production in the water of some dissolves substancess of Biological importance. Journal of Ecology, 18, 306-320.

[14] Zafar, A. R. (1966). Limnology of Hussiansagar Lake, Hydrabad, India phykas. Poll Res J., 5, 115-126.

[15] Shankar. P., Jayaraman. P. R., and Ganga Devi, T. (1996). Studies on the Hydrography of the lotic ecosystem 'Killiar' Thiruvanthapuram, Kerala, India. Poll. Res J., 21(2), 113-118.

[16] Olsen, R. D., Sommerfeld, M. R. (1977). The physiochemical limnology of desert reservoir. Hydrobiologia, 3J(2), 117-129.

[17] WHO. (1971). International standard for drinking water. Third edition, WHO, Geneva.

[18] Dwivedi, P. and Sonar, S. (2004). Evaluation of physiochemical and characteristics of water samples in water reservoir around Rono Hills, Doimukh (Dist.Papum pare), Arunachal Pradesh. Poll. Res J., 23(1), 101-104.

[19] Jain, C. K., Bhatia, K. S., and Vijay, T. (1997). Ground water quality in coastal region of Andra Pradesh. Indian Journal of Envirorn. Hith., 39(3), 182-192.

[20] Sahai, R. and Sinha, A. B. (1969). Investigations on Bioecology of Inland of Gorakhpur (U.P.) India 1, Limnology of Ramgarh Lake, Hydrobiologya, 34, 433-447.

[21] Hannam, H. (1979). Chemical modification in reservior regulated Streams In: The ecology of regulated streams (Eds) Ward, J.W. and Stanford. J.A. Edition plenum corporation publication, 75-94.

[22] Dwivedi, B. K. and Pandey, G. C. (2002). Physiochemical factors and algal diversity of two ponds (Girijakund and Maqubara pond) Faizabad, India. Poll Res J., 21(3), 361-369.

[23] Tiwari, F. (2013). Limnological Studies of Ramgarh lake in Eastern Uttar Pradesh, India. African Journal of Basic and Applied Sciences, 5(3): 145-148.

[24] Gupta, N., Pandey, P., and Hussain, J. (2017). Effect of physicochemical and biological parameters on the quality of river water of Narmada, Madhya Pradesh, India. Water Science, 31(1): 11-23.

[25] Jannat, N., Mottalib, A., and Nur Alam, M. (2019). Assessment of Physicochemical Properties of Surface Water of Mokeshbeel, Gazipur, Bangladesh. Journal of Environmental Science: Current Research, 2: 014.

[26] Javed, N., Prajapati, D. K., Singh, J., Gangwar, R. K., Deval, R. (2020). Assessment of Physico-chemical Properties of River Ramganga Water Quality in Moradabad and Bareilly Region of Uttar Pradesh, India. International Journal of Pharmaceutical Science and Research, 11(11): 5741-46.

[27] Mishra, S. and Kumar, A. (2021). Estimation of physicochemical characteristics and associated metal contamination risk in river Narmada, India. Environmental Engineering Research, 26(1): 190521. 